\title{
IT Governance in Airline Industry: A Multiple Case Study
}

\author{
Manar Iskandar, Noor Akma Mohd Salleh \\ Faculty of Business and Accountancy, University of Malaya, Kuala Lumpur, Malaysia
}

\begin{abstract}
Governance provides a controlled environment for IT and enables the organisations to align IT services with their objectives. IT governance is a must for any organization seeking to keep an eye on its investments. The move to e-commerce environment represents an opportunity as well as a threat. Airline industry has been heavily affected by this move. This paper discusses the role of IT governance in e-commerce environment by presenting three cases from airline industry in GCC countries. The IT governance framework for each airline company is analyzed. A summary of IT governance definitions, frameworks, and focus areas is provided.
\end{abstract}

\section{Introduction}

For most organizations, success in the achievement of business goals depends directly on the extent and capability of technology enablement. In such environment, governance over technology usage is as critical as any other corporate governance function. In fact, IT governance is a subset and integral part of corporate governance. Effective IT governance supports business goals, maximizes business investments in technology, and appropriately manages IT related opportunities and risks. IT governance ensures that IT goals are met and IT risks are mitigated such that IT delivers value to sustain and grow the business. IT governance drives strategic alignment between IT and the business and must judiciously measure performance. Good IT governance is essential to manage services, secure information, protect privacy and nurture corporate knowledge to grow as well as to endure economic and social changes happening globally as well as locally [4].

E-commerce presents one of the gigantic investments in IT. E-commerce investments are substantial and risky. Each and every organization should have a thorough measure that projects the risk, yield, and benefit of a project. Organizations can resolve this situation by implementing effective IT governance tools.
Airline industry was heavily affected by ecommerce technology, especially with the move to eticketing. On 1 June 2008, the industry moved to $100 \%$ e-ticketing as a requirement by The International Air Transport Association (IATA).

\section{Literature Review}

There were many attempts to define what is meant by "IT governance"? The following table summarizes those attempts in chronological order:

Table 1. IT Governance Definitions

\begin{tabular}{|l|l|l|}
\hline Authors & Year & Definition \\
\hline Luftman & 1996 & $\begin{array}{l}\text { Degree to which the } \\
\text { authority for making IT } \\
\text { decisions is defined and } \\
\text { shared among } \\
\text { management, and the } \\
\text { processes managers in } \\
\text { both IT and business } \\
\text { organizations apply in } \\
\text { setting IT priorities and } \\
\text { the allocation of IT } \\
\text { resources. }\end{array}$ \\
\hline BearingPoint & 2003 & $\begin{array}{l}\text { Structures and processes } \\
\text { that ensure that IT } \\
\text { supports the } \\
\text { organization's mission. } \\
\text { The purpose is to align IT } \\
\text { with the enterprise, } \\
\text { maximize the benefits of } \\
\text { IT, use IT resources } \\
\text { responsibly and manage } \\
\text { IT risks. }\end{array}$ \\
\hline $\begin{array}{l}\text { Van } \\
\text { Grembergen } \\
\text { and De Haes }\end{array}$ & 2003 \\
\hline Institute & $\begin{array}{l}\text { Responsibility of } \\
\text { executives and the board } \\
\text { of directors, and consists } \\
\text { of the leadership, } \\
\text { organizational structures } \\
\text { and processes that } \\
\text { ensure that the } \\
\text { enterprise's IT sustains } \\
\text { and extends the } \\
\text { organization's strategies } \\
\text { and objectives. }\end{array}$ \\
\hline $\begin{array}{l}\text { Organizational capacity } \\
\text { exercised by the Board, } \\
\text { executive management, }\end{array}$ \\
\hline
\end{tabular}




\begin{tabular}{|l|l|l|}
\hline & & $\begin{array}{l}\text { and IT management to } \\
\text { control the formulation } \\
\text { and implementation of IT } \\
\text { strategy and in this way, } \\
\text { ensure the fusion of } \\
\text { business and IT. }\end{array}$ \\
\hline $\begin{array}{l}\text { Schwarz and } \\
\text { Hirschheim }\end{array}$ & 2003 & $\begin{array}{l}\text { IT-related structures or } \\
\text { architectures (and } \\
\text { associated authority } \\
\text { patterns), implemented to } \\
\text { successfully accomplish } \\
\text { (IT-imperative) activities } \\
\text { in response to an } \\
\text { enterprise's environment } \\
\text { and strategic imperatives. }\end{array}$ \\
\hline $\begin{array}{l}\text { Simonsson } \\
\text { and Johnson }\end{array}$ & 2005 & $\begin{array}{l}\text { IT decision-making: The } \\
\text { preparation for, making of } \\
\text { and implementation of } \\
\text { decisions regarding } \\
\text { goals, processes, people } \\
\text { and technology on a } \\
\text { tactical and strategic } \\
\text { level. }\end{array}$ \\
\hline Weill and & 2006 & $\begin{array}{l}\text { Specifying the decision } \\
\text { rights and accountability } \\
\text { frameworks to encourage } \\
\text { desirable behavior in } \\
\text { using IT. IT governance } \\
\text { reflects broad corporate } \\
\text { governance principles, } \\
\text { while focusing on the } \\
\text { management and use of } \\
\text { IT to achieve corporate } \\
\text { governance goals. }\end{array}$ \\
\hline Webb, Pollard & 2006 & $\begin{array}{l}\text { Strategic alignment of IT } \\
\text { with the business such } \\
\text { and Rid maximum business } \\
\text { value is achieved through } \\
\text { the development and } \\
\text { maintenance of effective } \\
\text { IT control and } \\
\text { accountability, } \\
\text { performance } \\
\text { management and risk } \\
\text { management. }\end{array}$ \\
\hline & & \\
\hline & &
\end{tabular}

IT governance is an important element in any organization and has a great effect on its efficiency and effectiveness. Literature shows that governance has an impact on the firm's performance. Prior research on governance discovered that:

"Top-performing enterprises succeed where others fail by implementing effective IT governance to support their strategies. For example, firms with above-average IT governance following a specific strategy (for example, customer intimacy) had more than 20 percent higher profits than firms with poor governance following the strategy" [13]. Good governance of IT therefore is critical in supporting and enabling enterprise goals. IT governance is a promising newcomer which has appeared on the business radar. Other than achieving internal efficiency in IT organizations, IT governance supports the role of IT as a business enabler [10].

ISO 17799, COBIT, ITIL, Val IT are examples of IT governance frameworks. These frameworks or standards represent guidelines that help organizations to effectively implement IT governance. The following table summarizes these frameworks in alphabetical order:

Table 2. IT Governance Frameworks

\begin{tabular}{|c|c|}
\hline Framework & Summary \\
\hline COBIT & $\begin{array}{l}\text { Control Objectives for Information and } \\
\text { Related Technology (COBIT) has been } \\
\text { developed as a generally applicable and } \\
\text { accepted standard for good IT security } \\
\text { and control practices. The standards } \\
\text { include: (1) Performance measurement } \\
\text { elements, (2) A list of Critical Success } \\
\text { Factors (CSF) that provides succinct, non- } \\
\text { technical best practices for each IT } \\
\text { process, and (3) Maturity models to assist } \\
\text { in benchmarking and decision making for } \\
\text { capability improvements. }\end{array}$ \\
\hline COSO & $\begin{array}{l}\text { Committee of Sponsoring Organizations } \\
\text { (COSO) defined internal control as a } \\
\text { process, affected by an entity’s board of } \\
\text { directors, management and other } \\
\text { personnel, designed to provide reasonable } \\
\text { assurance regarding the achievement of } \\
\text { objectives in categories; effectiveness and } \\
\text { efficiency of operations, reliability of } \\
\text { financial reporting compliance with } \\
\text { applicable laws and regulations. }\end{array}$ \\
\hline ISO 17799 & $\begin{array}{l}\text { A standard for information security } \\
\text { including a comprehensive set of controls } \\
\text { and best practices in information security. } \\
\text { The standard is intended to serve as a } \\
\text { single reference point for identifying a } \\
\text { range of controls needed for most } \\
\text { situations where information systems are } \\
\text { used in industry and commerce. }\end{array}$ \\
\hline ITIL & $\begin{array}{l}\text { Information Technology Infrastructure } \\
\text { Library (ITIL) is the world-wide de facto } \\
\text { standard in Service Management. ITIL } \\
\text { provides a comprehensive, consistent } \\
\text { volume of best practices drawn from the } \\
\text { collective experience of thousands of IT } \\
\text { practitioners around the world. }\end{array}$ \\
\hline Val IT & $\begin{array}{l}\text { A governance framework that consists of } \\
\text { a set of guiding principles, and a number } \\
\text { of processes conforming to those } \\
\text { principles that are further defined as a set } \\
\text { of key management practices. Val IT } \\
\text { addresses assumptions, costs, risks and } \\
\text { outcomes related to a balanced portfolio } \\
\text { of IT-enabled business investments. }\end{array}$ \\
\hline
\end{tabular}

While a range of frameworks, standards and documents related to the control of IT exist, the primary focus of COBIT is on aligning the use of IT with the achievement of organizational goals. COBIT is a comprehensive framework of 34 control objectives that has been developed from 41 
international sources and validated internationally to help balance IT risk against investment in IT controls. The control objectives have been organized into a hierarchy of processes and domains that are designed to help bring about the alignment of business and IT objectives, by identifying the requirements for IT resources and information associated with 318 detailed control objectives. IT processes are grouped into four domains: planning and organization, acquisition and implementation, delivery and support and monitoring. As the framework considers all aspects of information and its supporting IT, management can use COBIT to help provide an appropriate control system for IT [.

Researchers did not provide guidelines on how to apply these frameworks in e-commerce environment. This presents a gap; hope to be filled by this research.

E-commerce is well known with its risks and vulnerabilities. That is due to the exposure of business's data and systems to unknown outsiders. The advent of e-commerce has affected organizations and their customers drastically [7], [8]. The risk of an enterprise not knowing the identity of its business partners is increased by e-commerce transactions and that requires a mutual effort of both IT and business management [5]. E-commerce is an inherently fragile intangible environment. Ecommerce systems are open to outside threats and attacks. E-business and e-commerce are more concerned with IT governance due to their inherent risks. These risks require the adoption of strong controls and management practices [2].

Airline industry has entered the e-commerce club. All possible safeguards for information privacy and security within the air transport industry must be implemented [10]. Airline industry operates in an extremely dynamic, and often highly volatile, commercial environment. Airline companies have sustainability risks (social, environmental, operational, strategic and financial risks) that have to deal with [14]. These risks can be managed and mitigated by implementing IT governance. IT governance will serve as a risk management and a performance measurement tool. This tool will eventually provide the necessary actions to be taken in order to sustain and extend the success of organizations in e-commerce environment especially in the airline industry. For this reason and with regards to what have been stated earlier, the need to study the role of IT governance becomes observable.

\section{Research Questions and Methodology}

There has been limited research in the area of IT governance in airline industry. An interpretive multiple case study approach has been selected as one appropriate way because it goes beyond describing and understanding a phenomenon.
Interpretive approaches examine, investigate, identify and analyze a phenomenon.

Research questions in a case study take the form of "how" and "why" [15]. These types of questions are also acceptable by the interpretive school [11].

In light of the discussion above, this research intends to respond to the following research questions:

Q1. What is the role of IT governance in airline industry?

Q2. How to achieve the desired role of IT governance in airline industry?

Q3. How to make use of IT governance frameworks in airline industry?

Quantitative research results in the field of IT governance are limited as they provide numerical descriptions rather than detailed narrative and generally provide less elaborate accounts of human perception. Qualitative research provides a thorough, holistic, in-depth understanding of human behavior and the reasons that govern such behavior. This study will be conducted using a qualitative approach, to be more specific, multiple interpretive case studies. Qualitative research helps in understanding the context within which human decisions and actions take place. Qualitative research argues that it is impossible why things happened in organizations without talking to individuals. It is only by talking to people, we can figure out what they understand [6]. Case studies are common in the interpretive tradition. They focus on human interpretation, meaning, behavior, and the reasons behind it. Interpretive case studies rely on interpretive and constructivist epistemology, i.e. social reality is socially constructed. In this type of case study, an attempt is made to understand phenomena through the meanings that people allocate to them. The plausibility of the story and the overall argument both define quality in interpretive case studies [6].

The method of semi-structured interviews is effective when researchers collect data from particular individuals by meeting with them only once. During a semi-structured interview, a researcher asks an interviewee questions based on a prepared written list of questions and topics. At the same time, the researcher encourages the interviewee to freely express ideas and provide information that the interviewee thinks is important. With this flexibility, the researcher can obtain unexpected significant information as well as answers for prepared interview questions. In addition to asking questions, researchers usually take notes and audiorecord interviews for later analysis. In order to conduct successful semi-structured interviews, researchers need to make interviewees feel comfortable about talking. Semi-structured interviews are conducted with a fairly open framework which allow for focused, conversational, two-way communication. They can be used both to 
give and receive information. Unlike the questionnaire framework, where detailed questions are formulating ahead of time, semi structured interviewing starts with more general questions or topics. Relevant topics are initially identified and the possible relationship between these topics and the issues become the basis for more specific questions which do not need to be prepared in advance. Not all questions are designed and phrased ahead of time. The majority of questions are created during the interview, allowing both the interviewer and the person being interviewed the flexibility to probe for details or discuss issues.

Semi-structured interviewing is guided only in the sense that some form of interview guide is prepared beforehand, and provides a framework for the interview.

IT directors, IT managers, internal audit directors, and internal audit managers were interviewed in addition to CEOs and VPs

The following questions have been asked during the interview:

-Could you describe the organizational structure of your department?

•How long have you been implementing IT governance?

-What IT governance tools are you using?

-Could you tell me about the entire process of the IT investment decision?

-How was the e-ticketing project initiated and developed?

-What types of changes have occurred after eticketing?

-How these changes affected IT governance?

-What type of risks identified before and after implementing e-ticketing?

-How did you manage these risks?

-How do you measure the effectiveness of IT governance?

-Who's responsible for setting IT governance policies and procedures?

-How do you achieve business/IT alignment?

-What performance measurements do you apply?

-What IT governance framework do you use? and why?

The three airline companies were selected based on their fleet size, annual profit, and IT governance implementation history. These companies are the national carriers of three GCC countries. The Cooperation Council for the Arab States of the Gulf, also known as the Gulf Cooperation Council (GCC) is a political and economic union established on 25 May 1981 involving the six Arab states of the Gulf: Bahrain, Kuwait, Oman, Qatar, Saudi Arabia and the United Arab Emirates. With regards to air transportation, GCC has made and still making extensive efforts in allowing national carriers to sell tickets directly without having to procure a general agent or GCC national sponsor, which would make it easier for GCC nationals and residents to get air tickets from the national carriers directly and would consequently increase the income of national carriers. Moreover, establishing a joint GCC office at IATA to coordinate GCC positions at the international events, follow up the developments in the air transportation and notify Member States of such developments.

\section{Discussion and Results}

Each company has been analyzed on the basis of the IT governance focus areas presented by the IT Governance Institute. The following table addresses those areas:

Table 3. IT Governance Focus Areas

\begin{tabular}{|c|l|}
\hline Focus Area & \multicolumn{1}{|c|}{ Description } \\
\hline $\begin{array}{c}\text { Strategic } \\
\text { alignment }\end{array}$ & $\begin{array}{l}\text { Focuses on aligning with the } \\
\text { business and collaborative } \\
\text { solutions. }\end{array}$ \\
\hline $\begin{array}{c}\text { Resource } \\
\text { management }\end{array}$ & $\begin{array}{l}\text { Optimizing knowledge and IT } \\
\text { infrastructure. }\end{array}$ \\
\hline $\begin{array}{c}\text { Performance } \\
\text { measurement }\end{array}$ & $\begin{array}{l}\text { Tracking project delivery and } \\
\text { monitoring IT services. }\end{array}$ \\
\hline Value delivery & $\begin{array}{l}\text { Concentrating on optimizing } \\
\text { expenses and proving the value of } \\
\text { IT. }\end{array}$ \\
\hline Risk management & $\begin{array}{l}\text { Addressing the safeguarding of IT } \\
\text { assets, disaster recovery and } \\
\text { continuity of operations. }\end{array}$ \\
\hline
\end{tabular}

\subsection{Airways}

It flies to more than 100 destinations in over 60 countries and operates nearly 700 flights per week across six continents. It was launched in 1985 with two leased aircraft from a rudimentary airport. Its phenomenal growth is reflected in the 130-plus aircraft in its rapidly expanding fleet - a mix of the latest wide-body Airbus and Boeing. In addition, it's a major player in the air freight industry, carrying 1.3 million tonnes of cargo in 2008, which amounted to almost $20 \%$ of the airline's $\$ 1.37$ billion net profit that year.

The IT governance department is responsible for the "Quality at Source" objective, including process management using CMMI, ITIL and COBIT frameworks, IT performance measurement, portfolio management and IT Strategy, in addition to managing the IT investment portfolio for the company. The initial phase of the COBIT implementation project was the formation of a project team consisting of five members from the security, operations, business consulting, and application development and support units in the IT department. The COBIT implementation project started by identifying the tangible and intangible IT 
assets and their owners. After the identification of IT assets and owners, the control owners and the responsible employees of IT processes included in COBIT were determined. Then, a COBIT gap analysis was performed by documenting the existing controls and control deficiencies.

In the future, the IT Department will use COBIT to measure the performance of IT processes, as performance measurement is vital for effective IT governance. The IT department's goal is to develop a process performance model, enabling the organization to keep track of performance of IT goals based on how they deliver and what they need to deliver. Key performance indicators (KPIs) and key goal indicators (KGIs) will be decided for each IT process. With the cooperation of IT and business senior management, standard performance targets and metrics of IT processes will be determined.

\subsection{Y Airways}

Travel by air has reached the point where it is now taken for granted in most corners of the globe. With larger number of passengers and more choice available in the skies, airlines looking to maintain and grow their position in the marketplace must provide a high-quality service with ever-increasing efficiency. In this highly competitive environment, this company has undergone a phenomenal expansion period, with an average of 35\% growth year-on-year for the past 10 years. Along the way, the airline has garnered many awards and accolades, becoming one of only six airlines worldwide to have been awarded a 5-star rating by Skytrax, an independent aviation industry monitor.

The Key to introducing COBIT was ensuring that all of IT and management understood why they needed to care about effective, value-focused controls. Getting them to realize that there are many important business reasons for this was the first key hurdle to be successfully addressed. COBIT's business-focused language allowed management, IT and internal audit to ensure they were on the same track.

The business process within IT has improved as a result of using COBIT for ongoing SOX compliance and other IT governance related projects. The company needs a strong governance model in place to approve, prioritize and manage IT investments on an ongoing basis. This is necessary to align IT investments with the business requirements needed to deliver IT value to the company. The process of IT governance must involve the business units at the highest level in a partnership with IT to ensure that effective strategic alignment is achieved.

\subsection{Z Airways}

The company started out in 1945 with a single twinengine DC-3 (Dakota). This was followed months later with the purchase of two more DC-3s, and these formed the nucleus of what in few years later was to become one of the world's largest airlines. Today, the company has 139 aircrafts, including the latest and most advanced wide-bodied jets presently available. It operates domestic and international scheduled flights to over 70 destinations in the Middle East, Africa, Asia, Europe and North America. In 2006, the company began the privatization process, dividing itself into Strategic Business Units (SBUs); the catering unit was the first to be privatized. In August 2007, the company board approved the conversion of strategic units into companies. It is planned that ground services, technical services, air cargo and the aviation academy, as well as the catering unit, will become subsidiaries of a holding company.

The IT governance framework consists of 20 partial processes, policies, procedures, controls, a self-testing program, the evidence, a document repository, and defined roles and responsibilities. COBIT is used as the basis for designing the framework. Specifically, they used the COBIT domains to assign process owners. The COBIT control objectives became the basis of their policies, and the COBIT control practices were used to write procedures. They also documented the roles and responsibilities in the procedures. The COBIT control practices were used to select key controls and the key controls were the subjects of self-tests.

\section{Conclusions}

Despite the fact that corporations are beginning to experience success with implementing IT governance mechanisms to better manage their IT resources, individual governance mechanisms cannot alone promise the successful implementation and execution of IT governance policies and procedures. Companies must be able to better understand the complex playing field of their competitive environment and be able to put together a reliable set of governance techniques that are simple, are easily shared and implemented, and that engage managers who make key decisions for the company [1].

The IT department and IT governance philosophies can no longer be a "black box," with board-level executives deferring to IT leadership for critical organizational policy decisions. With its critical contribution to corporate strategy, and the risk an organization faces by its mismanagement, IT governance can no longer be ignored by senior executives. Many organizations these days are struggling with getting IT governance implemented. The results of this research has provided a better guidance and explanation on which processes, structures, and relational mechanisms they can 
leverage to support a better alignment in their organizations.

Gaps in the field of IT governance have not been filled. To fill some of these gaps, this study has advanced the field of IT governance through unfolding the nature of IT governance in an airline industry environment. A major contribution that this research has made is the exploration of how IT governance induces desirable IT behaviors and consequently improved organizational performance in an airline industry context. Such a contribution is especially timely today, given the increasing prevalence of e-commerce-enabled business platforms.

This research will help the airline industry in providing insights about understanding the concept of IT governance, the role and the best frameworks that can assist the airline industry to operate effectively and efficiently, and how they are able to manage their resources, particularly that relate to IT investments, infrastructure, planning and projects by identifying e-commerce risks and ways to mitigate them.

\section{References}

[1] Chun, M. (2008) Creating an IT Governance Roadmap. Graziadio Business Report, vol. 11, no.3.

[2] Fink, D. (2004). Identifying and managing new forms of commerce risk and security. E-commerce security advice from experts, 112-121.

[3] IT Governance Institute. (2003). Board Briefing on IT Governance.

[4] ITGAF. (2008, 23 May 2010). Information Technology Governance Assurance Forum.

[5] Lainhart IV, J. (2000). IT Governance Can Help Guide Business eCommerce Initiatives. Information Systems Control Journal, 6.

[6] Myers, M. D. (2009). Qualitative Research in Business and Management. London: Sage Publications.

[7] Pathak, J. (2003). Internal audit and e-commerce controls. Internal Auditing-Boston-Warren Gorham and Lamont Incorporated-, 18(2), 30-34.

[8] Quaddus, M., and Achjari, D. (2005). A model for electronic commerce success. Telecommunications Policy, 29(2-3), 127-152.

[9] Ridley, G., J. Young, and P. Carroll. COBIT and its utilization: a framework from the literature. in System Sciences, 2004. Proceedings of the $37^{\text {th }}$ Hawaii International Conference on System Sciences.

[10] Simonsson, M., and Johnson, P. (2008). The IT organization modeling and assessment tool: Correlating IT governance maturity with the effect of IT. Proceedings of the $41^{\text {st }}$ Hawaii International Conference on System
Sciences.

[11] Walsham, G. (1995). Interpretive case studies in IS research: nature and method. European Journal of Information Systems, 4, 74-81.

[12] Wei, W., and Loho-Noya, M. (2008). Development of a Safeguard Model for E-Ticketing. http://www.swdsi.org

[13] Weill, P., and Ross, J. W. (2004). IT governance: How top performers manage IT decision rights for superior results: Harvard Business School Press.

[14] Yilmaz, A. K. (2008). The Corporate Sustainability Model for Airline Business. European Journal of Scientific Research, 22(3), 304-317.

[15] Yin, R. K. (2003). Case study research: Design and methods (Third ed.): Sage Publications, Inc. 